\title{
US grants support teraflop computing simulations
}

[WASHINGTON] The US Department of Energy (DOE) last week announced grants worth \$250 million over 10 years to five universities to help to develop the computational aspects of its effort to simulate phenomena associated with nuclear weapons.

Federico Peña, the Secretary of Energy, announced the selection of California Institute of Technology, Stanford University, University of Chicago, University of Illinois at Urbana/Champaign and University of Utah as 'centres of excellence' under the department's Academic Strategic Alliances Program (ASAP)

The programme is part of the larger Accelerated Strategic Computing Initiative, the department's plan to push the state of computational science beyond 100 teraflops by 2006 (a teraflop is a million million floating point operations per second).

The grant awards, selected from 49 proposals, will support the development of algorithms and computational approaches by the universities to help them to solve related, but unclassified, problems. The researchers will have access to three teraflop-scale computers at the department's nuclear weapons laboratories. About 10 per cent of the computers' operating time is expected to be devoted to university work, and converting the computers from classified to unclassified operation can take as little as 20 minutes.

Faculty and postdoctoral graduate researchers at each of the universities will receive about $\$ 5$ million annually to conduct research on physics-based modelling and high-performance computer simulation.
The problems to be addressed by the universities appear as relevant to industrial applications as to nuclear weapons research. Stanford, for example, will study the complex turbulent flows in aircraft jet engines.

Utah will work to provide a set of sciencebased tools for numerical simulation of accidental fires and explosions. And the California institute will investigate the effect of shock waves induced by high explosives on various materials in different phases, work that will be useful in areas such as mine accident rescue and building demolition.

Perhaps the most exotic winning proposal was that from Chicago. According to David Schramm, the university's vice-president, it will seek to unravel the astrophysical mystery of how a supernova explodes. Schramm says that, unlike the DOE, he will be able to continue testing his simulations in space.

John Hennessy, dean of engineering at Stanford, says the DOE computers are roughly two orders of magnitude more powerful than any now available to the university.

Victor Reis, assistant secretary of energy for defence programmes, says the DOE did not specify in the competition the research areas to be addressed. He says the aim is simply to "push" high performance computing, and make it work more efficiently.

C. Paul Robinson, director of Sandia National Laboratories, home to the first teraflops machine, says the main objective of ASAP is to develop algorithms and "equation solvers" to enable high-powered computers to run simulations as efficiently as possible.
DavidKramer

\section{Modest increase proposed for EU research budget}

[MUNICH] The European Commission last week proposed a small increase in the funding of research in the European Union's fifth multi-year Framework programme (FP5), due to start in 1999, to a total of ECU16.3 billion (US $\$ 17.5$ billion).

The commission's draft proposal for FP5, published in April, suggested concentrating research within three thematic programmes, each absorbing 24 per cent of an unspecified total budget. The remaining money would be divided between the union's nuclear research programme and three policy-orientated programmes, to support, for example, mobility of researchers.

The proposed budget represents an increase of about 3 per cent, over that of the current fourth Framework programme, of its proportion of the total gross national product of member states. But this may not be enough to satisfy the European Parliament, which must approve the programme and its budget jointly with the Council of Ministers.

Several years ago, the parliament demanded that the percentage of the commission's budget devoted to research should be increased from 4 to 6 per cent. It is not yet clear whether the commission's budget proposal represents a real increase in this factor.

Parliament's research committee presents its formal response to the FP5 proposal in mid-September. It is likely to request inclusion of an additional thematic programme on energy and the environment, and could also demand an even higher budget. The Council of Ministers is likely to be less enthusiastic about such a move.

Alison Abbot:

\section{Endangered species bill faces battle against property lobby}

[WASHINGTON] A bill introduced in the US

House of Representatives last week to reauthorize the Endangered Species Act (ESA) has been welcomed by environmentalists. But it is unlikely to settle deep differences with 'property rights' advocates.

The Endangered Species Recovery Act of 1997 (H.R. 2351), proposed by George Miller (Democrat, California), is the first ESA reauthorization bill to emerge in this session of Congress. The original act expired in 1992 after 20 years. Although its legal protection of endangered species remains, both environmentalists and property rights groups have been pressing for a new bill to remedy what they see as its shortcomings.

Miller's bill would make the primary goal of legislation the recovery of an endangered species to healthy status, rather than just the prevention of its extinction. That shift alone is likely to make it unacceptable to those who complain that the current act already places excessive restrictions on landowners.

Equally divisive is whether private owners of protected habitat who agree to conservation plans should be required to alter, or even scrap, development plans if the needs of a species changes. The Clinton administration, led by the Interior Secretary, Bruce Babbitt, has promoted such Habitat Conservation Plans, more than $\mathbf{4 0 0}$ of which have been either approved or proposed.

Babbitt has further promised landowners that once agreement is reached on such a plan, the government could not impose further restrictions for as long as 100 years. But many scientists, and virtually all environmental groups, oppose this 'no surprises' policy, saying it is not flexible enough to accommodate new scientific information (see Nature 386, 530; 1997).

Rather than strictly guaranteeing no surprises, Miller's bill calls for bonds, trust funds and tax incentives to help alleviate any financial burdens on landowners caused by compliance with the act.

On the same day that Miller introduced his legislation, Babbitt met with four Democratic and Republican senators who have been trying for months to negotiate a compromise on the new act.

Babbitt is said to have encouraged them to settle their differences on 'no surprises' and other issues, such as whether government agencies need to consult each other when determining the effects of land use on endangered species. But, says an aide to Senator Dirk Kempthorne (Republican, Idaho), a key figure in the negotiations, no solution is yet in sight. 